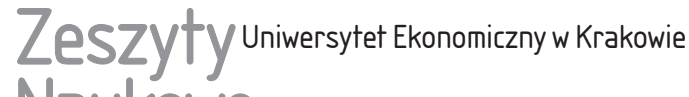 Naukowe
}

9(933)

ISSN 1898-6447

Zesz. Nauk. UEK, 2014; 9 (933): 95-108

DOI: 10.15678/ZNUEK.2014.0933.0907

Wojciech Ulrych

Department of Human Resource Management

University of Lodz

\section{The Constraints and Problems in Team Performance Management}

\begin{abstract}
A wide range of factors can affect team performance: setting clear and achievable goals, allocating individual work, utilizing an individual's skills, monitoring performance, maintaining team cohesion and identity, being able to handle internal conflicts, maintaining relationships with other teams, systems and resources available to teams and the quality of leadership. These problems and constraints affecting team performance management (TPM) are found on a global scale irrespective of a country's individual work culture.

This paper presents the nature of team performance management in order to discuss common TPM problems and constraints in the context of worldwide research findings. Environmental factors and team dynamics consistently influence team effectiveness. It is now clear that there is a need for future research to look at the complexity of team dynamics over time.
\end{abstract}

Keywords: team, performance management, IMO model, constraints, problems.

\section{Introduction}

Over the last decade a lot has been written about team performance management (TPM). Countless papers discuss either aspects of team management and literature reviews (e.g. Ilgen et al. 2005) or meta-analysis of TPM phenomena (e.g. Mathieu et al. 2008). It should come as no surprise that "a variety of global forces unfolding over the last two decades, however, have pushed organizations worldwide to restructure work around teams, to enable more rapid, flexible, and 
adaptive responses to the unexpected" (Kozlowski \& Ilgen 2006, p. 77). In the same vein Katzenbach and Smith (2001, p. 26) argue that teams should be the basic foundation of each organisation regardless of their size. They also reason, interestingly (2001, p. 127), that there is no one good model for a high performance team, because much of it depends on a team context that is sometimes beyond researchers. Yet they still put a lot of effort into working out their team models by composing different elements of the TPM puzzle. However, it is still a challenge. The reason for such failure may lay with a plethora of TPM variables which can influence overall team effectiveness.

This paper attempts to put together the most interesting constraints and problems TPM researchers have come across in their findings. It explores two main areas: 1) to present the nature of team performance management in order to 2) indicate TPM problems and constraints in the context of worldwide research findings. In this paper I don't attempt to present every single TPM constraint and problem found in the subject literature. Rather, those I highlight could show the way for future research moving towards much more integrated TPM and as a result improved team effectiveness. Given my aims here, the most appropriate team definition is Kozlowski and Bell's (2003, p. 334), which describes teams as "collectives which exist to perform organisationally relevant tasks, share one or more common goals, interact socially, exhibit task interdependencies, maintain and manage boundaries, and are embedded in an organizational context that sets boundaries, constrains the team, and influences exchanges with other units in the broader entity".

The first section is devoted to team effectiveness. The IMO model and its three stages are presented together with the dimensions which can influence team effectiveness. The second section examines TPM constraints and problems which are presented through the IMO perspective. It seems even more interesting in light of the fact that employee performance management (EPM) can hinder good teamwork (Armstrong 2009, p. 239), even though the same sequences can be used in EPM and TPM (p. 243). Nevertheless, Purcell, Hutchinson and Kinnie (1998, as cited by Armstrong 2009, p. 239) indicate that teams can be seen as "an elusive bridge between the aims of the individual employee and the objectives of the organisation (...) teams can provide the medium for linking employee performance targets to the factors critical to the success of the business".

\section{Team Effectiveness from the IMO Perspective}

McGrath's (1984) IPO (i.e. inputs $\rightarrow$ processes $\rightarrow$ outcomes) model represents a typical business process. From this viewpoint its "inputs" contain individual 
KASOC (i.e. knowledge, abilities, skills and other characteristics; see: Bernardin 2010, p. 92), team level factors (i.e. task structure, objectives, resources) and organisational and contextual factors (i.e. organisational structure and environmental complexity). They are all directed towards team "outcomes" in the form of performance and its members' reactions (Mathieu et al. 2008, p. 413). The IPO model has been modified in several ways, but especially the wider contextual factors discussed by, among others, Cohen and Bailey (1997, p. 244) seem to be of the highest importance for TPM. However, not everything that happens in an IPO processes' stage can be treated as a process (Ilgen et al. 2005, p. 520), just like the psychological traits or the emotional states of its members. That is why the "processes" stage (i.e. member's action) in the IPO model was enriched by "emergent states" (e.g. psychological traits) that ultimately advanced the IPO into the IMO (i.e. inputs $\rightarrow$ mediators $\rightarrow$ outcomes) model (Ilgen et al. 2005).

The IMO model is currently widely accepted in the team management literature. On one hand it indicates the changing dynamic nature of teamwork as team members mature (Kozlowski et al. 1999). At the same time, however, many different team processes don't happen simultaneously (Marks, Mathieu \& Zaccaro 2001, McGrath 1984). In addition, the processes happen in a cyclical nature as the team functions. This is why the IMO framework is often depicted as IMOI, i.e. inputs $\rightarrow$ mediators $\rightarrow$ outputs $\rightarrow$ inputs (Ilgen et al.2005).

The IMO perspective enables one to look more closely into the different dimensions of team effectiveness. Although the compilation of such dimensions is rather challenging, most of them are arranged in Table 1 to show a "general picture". Hiding behind each dimension are often complex and ambiguous phenomena depicted in the form of variables. It would be far beyond the scope of this paper to go into the details of each of these dimensions. But it is precisely those details that are necessary to provide the "big picture".

The input stage consists of three areas: team composition level (i.e. individual level), team level and organisational / contextual level.

Through the years of team work research two general approaches to "team composition" have been worked out: individual-based models and team-based models (Mathieu et al. 2014, p. 132). Team composition includes a variety of attributes which influence the remaining two IMO stages. In general, all dimensions of the team composition category mentioned in Table 1 show a positive relationship between themselves and team performance. As far as personality is concerned, there is substantial research supporting the validity of the five-factor model ("Big Five") in the prediction of a number of criteria (e.g. performance, sales, counterproductive behaviours) for a variety of jobs (Bernardin 2010, p. 186). Belbin (2010, p. 23) indicated that complementary combinations of team key roles proved to be more effective than connecting people with similar profiles who usually begin 
to compete with each other. Many personality traits (e.g. extraversion, emotional stability, and openness to experience) positively correspond to team performance (Bell 2007). In turn the question of competencies (i.e. KASOCs) shows that, for high performance, a different set of competencies is needed for both individuals working alone and team members working in cooperation (e.g. Morgeson, Reider $\&$ Campion 2005). The other attributes notion consists of many characteristics. Among them, Mathieu et al. (2008, p. 437) point out goal and team orientation as well as team values. It is interesting that team learning orientation can have both positive and negative consequences (Bunderson \& Sutcliffe 2003). Findings highlight that "diversity is a complex input factor (i.e. in terms of demographic, functional background, personality, and attitudes/values) in team effectiveness models, with studies reporting diversity as being beneficial, detrimental, and having no impact on processes, states, and performance" (Webber \& Donahue 2001, as cited by: Mathieu et al. 2008, p. 438). In turn complex combination represents much more sophisticated approaches to all the above dimensions and refers to subgroups, position / status and the network of communication.

Table 1. The IMO-based Various Team Dimensions Which Influence Team Outcomes

\begin{tabular}{|c|c|c|c|}
\hline \multirow{2}{*}{ Inputs } & \multicolumn{2}{|c|}{ Mediators } & \multirow{2}{*}{ Outcomes } \\
\hline & team processes & emergent states & \\
\hline $\begin{array}{l}\text { Team composition level } \\
\text { - Personality } \\
\text { - Competencies } \\
\text { - Other attributes } \\
\text { - Diversity factors } \\
\text { (demography, functional, } \\
\text { attitudes/values) } \\
\text { - Complex combinations }\end{array}$ & $\begin{array}{l}\text { - Transition processes } \\
\text { - Action } \\
\text { - Interpersonal } \\
\text { - Others }\end{array}$ & $\begin{array}{l}\text { - Team confidence } \\
\text { - Empowerment } \\
\text { - Team climate } \\
\text { - Cohesion } \\
\text { - Trust } \\
\text { - Collective cognition }\end{array}$ & $\begin{array}{l}\text { Team performance } \\
\text { behaviours }\end{array}$ \\
\hline $\begin{array}{l}\text { Team level } \\
\text { - Interdependence } \\
\text { - Technology / virtuality } \\
\text { - Team training } \\
\text { - Team leadership } \\
\text { - Team structure }\end{array}$ & \multirow{2}{*}{\multicolumn{2}{|c|}{$\begin{array}{l}\text { Blended mediators } \\
\text { - Team learning } \\
\text { - Behavioural integration } \\
\text { - Transitive memory }\end{array}$}} & $\begin{array}{l}\text { Performance } \\
\text { composite }\end{array}$ \\
\hline $\begin{array}{l}\text { Organisational / } \\
\text { contextual level }\end{array}$ & & & \\
\hline
\end{tabular}

Source: the author's own compilation based on (Mathieu et al. 2008).

The "team level" consists of five areas: interdependence, virtuality, training, leadership, and team structure. Interdependence describes "the extent to which team members cooperate and work interactively to complete tasks" (Stewart \& 
Barrick 2000, p. 137) and can be discussed from the perspectives of input, process and outcome (Mathieu et al. 2008, p. 443). Outcome is the most important because "individual feedback and rewards should be linked to the group's performance in order to motivate group-oriented behavior" (Campion, Medsker \& Higgs 1993, p. 827). Technology / virtuality findings on teams are ambiguous. However, some of them point to leadership behaviours as drivers of virtual team performance (Carte, Chidambaram \& Becker 2006). Key questions about team training remain about "what" to train, "how" to train, and "when" to train (Kozlowski \& Bell 2003), and most researchers share the opinion that it should refer to employee team members (Mathieu et al. 2008, p. 447). Traditional leadership and its influence on team performance is widely presented in literature reviews and has a positive influence on team performance (Mathieu et al. 2008, p. 449). In recent years shared leadership (i.e. "it emerges from within the team itself") research has been a key area of interest for researchers. Although little research has been done in this area, most researchers hold the opinion that it is positively related to team performance (e.g. Carson, Tesluk \& Marrone 2007).

The organisational / contextual level consists of an HR system, climate and culture. It is obvious that teams operate in an organisational context that either facilitates or hinders its functioning, and the team itself has to be treated as the primary level of analysis (Gully 2000, p. 27, as cited by: Mathieu et al. 2008, p. 454). In turn, one of a few High Performance Work Systems (HPWS) is a "high percentage of workforce working in self-managed, project-based work teams" (Bernardin 2010, p. 6).

All of these input-stage "inputs" influence the next IMO stage, which is called "mediators". It consists of two areas: processes and emergent states.

Team processes have played a central role in most, if not all, team effectiveness models (Mathieu et al. 2008, p. 421). Marks, Mathieu \& Zaccaro (2001) divided team processes into three categories:

- transition processes, in which team members focus on activities such as mission analysis, planning, goal specification and formulating strategies,

- action processes, in which members concentrate on task accomplishments, monitoring progress and systems, coordinating team members, as well as monitoring and backing up their fellow team members,

- and interpersonal processes, which include conflict management, motivation and confidence building, and affect.

In their review of the literature, Mathieu et al. (2008, p. 420) found many positive connections between team performance and time management, collective leadership and the quality of team performance plans. Transition processes, however, have received the least empirical attention among the processes. Meanwhile action processes, e.g. communication, coordination, participation and 
information sharing, have been widely presented for their positive influence on team performance (Mathieu et al. 2008, p. 422). In addition, task conflict may positively influence team performance, and feedback has a positive impact on motivation, interpersonal trust, and ultimately performance in virtual teams. Bradley, White \& Mennecke (2003) concluded that there is abundant support for the contention that interpersonal processes relate positively to team performance when teams engage in longer-term tasks. Team creative processes ("other processes" category, Table 1) have a significant positive effect on performance (Gilson et al. 2005), although they are not interpersonal processes. In turn there is a dearth of research into creative processes and affective outcomes (Mathieu et al. 2008, p. 423).

Marks, Mathieu \& Zaccaro (2001, p. 357) described emergent states as "cognitive, motivational, and affective states of teams [that are] (...) dynamic in nature and vary as a function of team context, inputs, processes, and outcomes". Emergent states include: team confidence (which includes team efficacy, i.e. "the team's belief in success on a specific task" and potency, i.e. "the team's belief in success on a variety of tasks and in different contexts"), empowerment, team climate, cohesion (i.e. the commitment of team members to the team's overall task or to each other), trust and collective cognition. In general, research indicates a positive correlation between emergent states and team performance (Mathieu et al. 2008, pp. 424-30).

Team outcomes make up the last IMO stage. They are usually considered in terms of 1) performance effectiveness assessed in terms of the quantity and quality of outputs and 2) individual attitudes and behavioural outcomes (Cohen \& Bailey 1997, p. 243). In general it is important "what" has to be done (i.e. outcome, standards of performance) and "how" it is to be done (i.e. competencies, personal traits). Nevertheless Mathieu et al. (2008, pp. 415-17) in their review of the team performance literature presented four outcome categories:

- organisational-level performance, which refers to top management teams but may concern the question of teams interdependence too,

- team performance behaviours (e.g. team feedback seeking; learning behaviors, error discussion) and outcomes as a result of performance behaviours (e.g. managers' rating scale usage, measuring sales or indices of effectiveness),

- role-based performance, which refers to team members competencies necessary to perform their jobs,

- and performance composite, as a blended measure of team outcomes, which is based on different team functions, and as a result produces a blended set of different indicators, from planning and problem solving measures to productivity and overall effectiveness.

When measuring team performance there are also types of criteria which refer to team members' affective reactions and team viability. Affective reactions 
research generally refers to team atmosphere and how members are treated (Janssen, Van de Vliert \& Veenstra 1999). In turn team viability remains a popular criterion measure yet suffers from a great deal of ambiguity (Barrick et al. 2007). It is usually associated with the team-level criterion, while members who wish to remain a team member, satisfaction, team climate, team commitment and group cohesion are used as indicators of viability (Mathieu et al. 2008, p. 418).

\section{TPM Problems and Constraints in the Context of the IMO Findings}

Team performance management activities follow the same sequence as employee performance management activities, and include the following (Armstrong 2009, p. 243):

- agreeing objectives,

- formulating plans to achieve objectives,

- implementing plans,

- monitoring progress,

- reviewing and assessing achievement,

- redefining objectives and plans in the light of performance appraisals.

Taking into account Armstrong's previous statement it is worth remembering that in the field of EPM there are many authors who share the belief that the same three-step process - planning, supporting and appraising performance - is paramount (e.g. Armstrong 2009, p. 309; Houldsworth \& Jirasinghe 2006, p. 104; Williams 2006, p. 13). In addition, Armstrong (2009, p. 243-44) interestingly states that: 1) "work objectives for teams are set in much the same way as individual objectives", 2) "process (i.e. of TPM) objectives are also best defined by the team getting together and agreeing how they should conduct themselves as a team" and 3) "team performance review meetings analyze and assess feedback and control information on their joint achievements against objectives and project plans" with "a review of the individual contribution made by each team member - i.e. peer review". Such TPM activities include a wide variety of deeds and decisions that people (i.e. supervisor and team members) should take on as a team. More importantly, some TPM activities should be similar to those of EPM.

Indeed, some EPM and TPM solutions seem to be consistent. For instance, Egan (1995) explains that the whole process of EPM, coaching, consultation, feedback and all kinds of staff support should encourage each employee to develop. Additionally, he concluded: "It would be perfect if teams developed in the same manner" (Egan 1995, p. 34). However, following this mindset can bring about some important consequences that can be difficult to put into practice due to 
the findings shown in Table 2. For instance, Furnham (2004, p. 84-85) indicates that not all goals can be pursued at the same time because the system can be simply overloaded. He also adds that EPM works best if the goals are clear, and their number is limited. This assumption is challenging due to the constraints and problems listed in Table 2, which highlights the lack of a clear connection between individual, team and overall organisational effectiveness. Beyond that, some assumptions on EPM already seem to be outdated and cannot keep up with both employee and team management. For example, Buchner (2007) indicates that many market trends such as downsizing, decentralisation and distance working can make it impossible for a manager to either observe a worker in the traditional way or devote enough time to this activity. Besides, at present employees have different expectations as to how to provide feedback and performance management. Research also indicates that the process of motivating, and even the collection and transfer of information feedback, can be transferred from the manager to the employee (Buchner 2007, pp. 61-62).

If one considers team management activities from an IMO viewpoint then there is an opportunity to observe the constraints and problems of team effectiveness (Table 2). In other words, such a perspective sees real human activities clash with the various team dimensions that influence team outcomes.

Table 2. The IMO-based Selected Constraints and Problems of Team Performance from the Viewpoint of Armstrong's TPM Activities

\begin{tabular}{|c|c|}
\hline TPM / IMO & $\begin{array}{c}\text { Constraints and Problems that Come from the IMO Model } \\
\text { (Inputs } \rightarrow \text { Mediators } \rightarrow \text { Outcomes) }\end{array}$ \\
\hline $\begin{array}{l}\text { Planning } \\
\text { performance: } \\
\text { - agreeing objectives, } \\
\text { - formulating plans to } \\
\text { achieve objectives }\end{array}$ & $\begin{array}{l}\text { - The question of clear connection of individual, team and overall } \\
\text { organisational effectiveness still remains unsolved (Mathieu et al. } \\
\text { 2008, p. 419). Thus, objectives don't have to stay the same over time as } \\
\text { contextual factors influence employee activities and decisions. } \\
\text { - There is still a lot of trouble understanding team composition and how } \\
\text { to model its influences on team outcomes (Mathieu } \text { et al. 2014, p. 132). } \\
\text { - There are no guarantees that having talented individual members will } \\
\text { ensure team effectiveness, (...) although it enhances its likelihood } \\
\text { of success (Mathieu et al. 2014, p. 136). } \\
\text { - Belbin (2010, p. 25) indicates that in reality it is difficult to find } \\
\text { a team composition in which every team member holds his or her job } \\
\text { according to the proper key team role. } \\
\text { - The benefits of training individuals versus training teams still } \\
\text { represents limited empirical evidence (Kozlowski \& Bell 2003, p. 357). } \\
\text { - Transition processes have received the least empirical attention in the } \\
\text { processes category of the mediators (Mathieu et al. 2008, p. 420). } \\
\text { - Negative members can exert a very high disproportionate influence } \\
\text { on team activities and effectiveness, and their presence should be } \\
\text { considered in team composition frameworks (Felps, Mitchell \& } \\
\text { Byington 2006). }\end{array}$ \\
\hline
\end{tabular}


Table 2 cnt'd

\begin{tabular}{|c|c|}
\hline TPM / IMO & $\begin{array}{l}\text { Constraints and Problems that Come from the IMO Model } \\
\text { (Inputs } \rightarrow \text { Mediators } \rightarrow \text { Outcomes) }\end{array}$ \\
\hline $\begin{array}{l}\text { Supporting } \\
\text { performance: } \\
\text { - implementing plans, } \\
\text { - monitoring progress }\end{array}$ & $\begin{array}{l}\text { - Performance behaviours (e.g., learning) are sometimes considered } \\
\text { outcomes (Edmondson 1999) or creativity (Gilson \& Shalley 2004) as } \\
\text { well as mediators (e.g., Gilson et al. 2005). } \\
\text { - One of the frequently voiced criticisms of individual performance } \\
\text { management is that it inhibits good teamwork (Armstrong 2009, p. 239). } \\
\text { - The reason for this can be derived from the findings that individual } \\
\text { learning and competencies development can prevent teams from } \\
\text { performing well in the short run (Bunderson \& Sutcliffe 2003). } \\
\text { - The individual composition models implicitly assume that the } \\
\text { contributions of different members to overall team effectiveness are } \\
\text { comparable. But that may not be the case (Mathieu et al. 2014, p. 138). } \\
\text { - "It is assumed, but rarely ever directly assessed in research, that } \\
\text { members' performance of task roles contributes to team effectiveness } \\
\text { more or less directly through aggregation of accomplishments related to } \\
\text { team tasks" (LePine } \text { et al. 2011, p. 319). } \\
\text { - The composition of virtual teams may differ markedly from those who } \\
\text { would be on the team if they had to be placed (Mathieu } \text { et al. 2008, } \\
\text { p. } 452 \text { ). } \\
\text { - From an interpersonal processes viewpoint it is known that both } \\
\text { relationship and task conflict have strong, negative correlations with } \\
\text { team performance and member satisfaction (De Dreu \& Weingart } \\
\text { 2003). } \\
\text { - "Team potency" can have negative implications on performance in the } \\
\text { case of service quality (De Jong, De Ruyter \& Wetzels 2005). }\end{array}$ \\
\hline $\begin{array}{l}\text { Reviewing } \\
\text { performance: } \\
\text { - reviewing } \\
\text { and assessing } \\
\text { achievement, } \\
\text { - redefining objectives } \\
\text { and plans in the light } \\
\text { of the performance } \\
\text { appraisal }\end{array}$ & $\begin{array}{l}\text { - The question of time is particularly relevant to the collection of team } \\
\text { outcome data, and time lags have not been sufficiently considered } \\
\text { (Mathieu et al. 2008, p. 419). } \\
\text { - Performance is context specific; "what" to use as criteria measures } \\
\text { and "when" to use them in terms of team maturity is a challenging } \\
\text { opportunity (Mathieu et al. 2008, p. 419). } \\
\text { - A team's life cycle whether it be a project-based team, production team } \\
\text { or sales team can vary tremendously leading to difficulties in precisely } \\
\text { measuring team processes and outcomes (Mathieu et al. 2008, p. 419). } \\
\text { - Affective reactions and team viability are not often used as primary } \\
\text { criteria because of their ambiguity, self-report nature and their lack of } \\
\text { validity from team performance (Mathieu et al. 2008, p. 418). } \\
\text { - Martins, Gilson \& Maynard (2004) highlighted that not all virtual } \\
\text { teams are similar to one another, so researchers should consider the } \\
\text { effects that the extent of a team's virtuality can have on mediators and } \\
\text { outcomes and thus performance. }\end{array}$ \\
\hline
\end{tabular}

Source: the author's own compilation based on different authors.

In addition, empirical analyses have demonstrated that different processes and (or) emergent states are highly correlated with one another or even among each 
other (Mathieu et al. 2008, p. 432). This makes explaining team performance using each of these variables far more difficult. One of the reasons for this inconvenience is the needs to measure both team processes and emergent states at the same time.

\section{Conclusion}

Table 2 merely adumbrates the TPM constraints and problems - but in an interesting form of "similar-to-EPM" perspective. It is clear that both EPM and TPM research are still changing and facing challenges. Numerous authors have referred to the problems discussed in this paper. In their review on team management research, Cohen and Bailey (1997, pp. 244-45) presented their model of team effectiveness. They indicated wisely that "variables listed under each category are meant as examples; they do not constitute an exhaustive listing". They knew that the model was just "to help us make sense out of a complex set of relationships and to suggest directions for future work". That is why so many questions still remain. Ten years later Mathieu et al. (2008, p. 460-62) suggested that much progress in team effectiveness research had been done although two questions still represent prime areas for future research: 1) to what extent do environmental factors influence team job design characteristics and 2) how do team dynamics influence effectiveness in time? In addition, the authors (pp. 441-60) listed a variety of problems to be solved comprising all three "inputs" levels of the IMO model.

Mathieu et al. (2008, pp. 460-62) also indicated that research work is more and more defragmented, with advancing and testing complex models and simulations. Moreover, they suggest that the IPO/IMOI models are most suitable for situations where "a given set of members operate within a clearly defined boundary for a set period of time and produce some quantifiable outputs or services". They say that the dynamics of modern-day teamwork require many nuances which are not currently captured to be taken into consideration, e.g. some members work for long periods together whilst others don't; some join the team, others leave; some are more individual, others are not; a team leader may play different roles at each stage of team projects; the team may break into sub-teams. All these instances can be called the "dynamic inputs" to their later processes, emergent states and outcomes. Moreover, organisational and environmental contextual factors are not static and change over time. That is why there is a need for future research to embrace the complexity of team dynamics over time in a changing environment. The question of time influences results in many ways. For example, if age diversity has a generally detrimental influence on conflict management and performance, 
this effect decreases as time goes by and members spend more and more time working together (Harrison, Price \& Bell 1998).

Practical advice for team managers and team participants themselves isn't so easy. TPM is much more complicated than EPM, although they embrace the same activities of planning, supporting and reviewing performance. The bottom line is that team managers should be aware of a wider range of team effectiveness variables. However, a few general conclusions on team management may come down to the following ideas: the changing environment constantly drives team changes. Managerial experience gained in a stable team environment may no longer be helpful given today's complexity of team dynamics. This is why working with different teams in different environments over a longer period of time may produce more sufficient and diverse practical experience, which in turn can help to achieve the expected team results. However, in some cases rich managerial experience may not be enough. It doesn't come as a surprise that in some circumstances managers have to delegate some of their managerial functions to team participants in order to maintain overall control.

To summarise, only a few findings have already been presented in the form of dynamic team membership relationships (Mathieu et al. 2014, p. 148) and there is still much ahead. However, the trend is clear due to the fact that "to fully understand work teams, researchers must investigate how team dynamics develop and change over time" (Gully 2000, p. 35). Unfortunately, very little research has been done in this area. However, Mathieu et al. (2014, pp. 145-46), invoking other authors' findings, highlights that we have to take into consideration numerous factors that have influences on team processes and effectiveness both in a team's early life cycle (e.g. members' demographics or uncertainty avoidance) and its later life cycle (e.g. members' personalities, beliefs and attitudes).

\section{Bibliography}

Armstrong M. (2009), Armstrong's Handbook of Performance Management. An Evidence-based Guide to Delivering High Performance, $4^{\text {th }}$ ed., Kogan Page.

Barrick M. B., Bradley B. H., Kristof-Brown A. L., Colbert A. E. (2007), The Moderating Role of Top Management Team Interdependence: Implications for Real Teams and Working Groups, "Academy of Management Journal", 50: 544-557, http://dx.doi. org/10.5465/AMJ.2007.25525781.

Belbin M. (2010), Nie tylko zespót, Oficyna a Wolters Kluwer business, Warszawa.

Bell S. T. (2007), Deep-level Composition Variables as Predictors of Team Performance: A Meta-analysis, "Journal of Applied Psychology", 92: 595-615, http://dx.doi. org/10.1037/0021-9010.92.3.595.

Bernardin H. J. (2010), Human Resource Management: An Experiential Approach, $4^{\text {th }}$ ed., McGraw-Hill International Edition. 
Bradley J., White B. J., Mennecke B. E. (2003), Teams and Tasks - A Temporal Framework for the Effects of Interpersonal Interventions on Team Performance, "Small Group Research", 34(3): 353-387, http://dx.doi.org/10.1177/1046496403034003004.

Buchner T. W. (2007), Performance Management Theory: A Look from the Performer's Perspective with Implications for HRD, "Human Resource Development International", vol. 10, nr 1: 59-73, http://dx.doi.org/10.1080/13678860601170294.

Bunderson J. S., Sutcliffe K. M. (2003), Management Team Learning Orientation and Business Unit Performance, "Journal of Applied Psychology", 88: 552-560, http:// dx.doi.org/10.1037/00219010.88.3.552.

Campion M. A., Medsker G. J., Higgs A. C. (1993), Relations between Work Group Characteristics and Effectiveness: Implications for Designing Effective Work Groups, "Personnel Psychology", 46: 823-850, http://dx.doi.org/10.1111/j.1744-6570.1993. tb01571.x.

Carson J. B., Tesluk P. E., Marrone J. A. (2007), Shared Leadership in Teams: An Investigation of Antecedent Conditions and Performance, "Academy of Management Journal”, 50: 1217-1234, http://dx.doi.org/10.2307/AMJ.2007.20159921.

Carte T. A., Chidambaram L., Becker A. (2006), Emergent Leadership in Self-managed Virtual Teams, "Group Decision and Negotiation", 15: 323-343, http://dx.doi. org/10.1007/s10726-006-9045-7.

Cohen S. G., Bailey D. E. (1997), What Makes Teams Work: Group Effectiveness Research from the Shop Floor to the Executive Suite, "Journal of Management", 23: 239-290, http://dx.doi.org/10.1177/014920639702300303.

De Dreu C. K. W., Weingart L. R. (2003), Task versus Relationship Conflict: Team Performance, and Team Member Satisfaction: A Meta-analysis, "Journal of Applied Psychology", 88: 741-749, http://dx.doi.org/10.1037/0021-9010.88.4.741.

De Jong A., De Ruyter K., Wetzels M. (2005), Antecedents and Consequences of Group Potency: A Study of Self-managing Service Teams, "Management Science", 51: 16101625, http://dx.doi.org/10.1287/mnsc.1050.0425.

Edmondson A. (1999), Psychological Safety and Learning Behavior in Work Teams, "Administrative Science Quarterly", 44: 350-383, http://dx.doi.org/10.2307/2666999.

Egan G. (1995), A Clear Path to Peak Performance, "People Management", vol. 1, nr 10: 34-37.

Felps W., Mitchell T. R., Byington E. (2006), How, When, and Why Bad Apples Spoil the Barrel: Negative Group Members and Dysfunctional Groups, "Research in Organizational Behavior", 27: 175-222, http://dx.doi.org/10.1016/S0191-3085(06)27005-9.

Furnham A. (2004), Performance Management Systems, "European Business Journal", vol. 16(2): 83-94.

Gilson L. L., Mathieu J. E., Shalley C. E., \& Ruddy T. M. (2005), Creativity and Standardization: Complementary or Conflicting Drivers of Team Effectiveness, "Academy of Management Journal", 48: 521-531, http://dx.doi.org/10.5465/AMJ.2005.17407916.

Gilson L. L., Shalley C. E. (2004), A Little Creativity Goes a Long Way: An Examination of Teams' Engagement In Creative Processes, "Journal of Management", 30: 453-470, http://dx.doi.org/10.1016/j.jm.2003.07.001.

Gully S. M. (2000), Work Teams Research: Recent Findings and Future Trends (in:) M. M. Beyerlein (ed.), Work Teams: Past, Present and Future, Kluwer Academic, The Netherlands. 
Harrison D. A., Price K. H., Bell M. P. (1998), Beyond Relational Demography: Time and the Effects of Surface and Deep-level Diversity on Work Group Decisions, "Academy of Management Journal", 41: 96-107, http://dx.doi.org/10.2307/256901.

Houldsworth E., Jirasinghe D. (2006), Managing and Measuring Employee Performance, Kogan Page.

Ilgen D. R., Hollenbeck J. R., Johnson M., Jundt D. (2005), Teams in Organizations: From Input-process-output Models to IMOI Models, "Annual Review of Psychology", 56: 517-543, http://dx.doi.org/10.1146/annurev.psych.56.091103.070250.

Janssen O., Van de Vliert E., Veenstra C. (1999), How Task and Person Conflict Shape the Role of Positive Interdependence in Management Teams, "Journal of Management", 25: 117-141, http://dx.doi.org/10.1177/014920639902500201.

Katzenbach J. R., Smith D. K. (2001), Siła zespołów. Wpływ siły zespołowej na efektywność organizacji, Oficyna Ekonomiczna, Oddział Polskich Wydawnictw Profesjonalnych, Kraków.

Kozlowski S. W. J., Bell B. S. (2003), Work Groups and Teams in Organizations (in:) W. C. Borman, D. R. Ilgen, R. J. Klimoski (eds), Handbook of Psychology: Industrial and Organizational Psychology, vol. 12, Wiley, London.

Kozlowski S. W. J., Gully S. M., Nason E. R., Smith E. M. (1999), Developing Adaptive Teams: A Theory of Compilation and Performance across Levels and Time (in:) D. R. Ilgen, E. D. Pulakos (eds), The Changing Nature of Work Performance: Implications for Staffing, Personnel Actions, and Development, Jossey-Bass, San Francisco.

Kozlowski S. W. J., Ilgen D. R. (2006), Enhancing the Effectiveness of Work Groups and Teams, "Psychological Science in the Public Interest", vol. 7, nr 3, 77-124, http:// dx.doi.org/10.1111/j.1529-1006.2006.00030.x.

LePine J. A., Buckman B. R., Crawford E. R., Methot J. R. (2011), A Review of Research on Personality in Teams: Accounting for Pathways Spanning Levels of Theory and Analysis, "Human Resource Management Review", 21, 311-330, http://dx.doi. org/10.1016/j.hrmr.2010.10.004.

Marks M. A., Mathieu J. E., Zaccaro S. J. (2001), A Temporally Based Framework and Taxonomy of Team Processes, "Academy of Management Review", 26(3): 356-376, http://dx.doi.org/10.5465/AMR.2001.4845785.

Martins L. L., Gilson L. L., Maynard M. T. (2004), Virtual Teams: What Do We Know and Where Do We Go from Here?, "Journal of Management", 30: 805-835, http:// dx.doi.org/10.1016/j.jm.2004.05.002.

Mathieu J., Maynard M. T., Rapp T., Gilson L. (2008), Team Effectiveness 1997-2007: A Review of Recent Advancements and a Glimpse into the Future, "Journal of Management", 34(3): 410-476, http://dx.doi.org/10.1177/0149206308316061.

Mathieu J. E., Tannenbaum S. I., Donsbach J. S., Alliger G. M. (2014), A Review and Integration of Team Composition Models Moving toward a Dynamic and Temporal Framework, "Journal of Management", 40(1): 130-160, http://dx.doi. org/10.1177/0149206313503014.

McGrath J. E. (1984), Groups: Interaction and Performance, Prentice Hall, Englewood Cliffs, NJ.

Morgeson F. P., Reider M. H., Campion M. A. (2005), Selecting Individuals in Team Settings: The Importance of Social Skills, Personality Characteristics, and Teamwork Knowledge, "Personnel Psychology", 58: 583-611, http://dx.doi.org/10.1111/j.17446570.2005.655.x. 
Purcell J., Hutchinson S., Kinnie N. (1998), The Lean Organisation, IPD, London.

Stewart G. L., Barrick M. R. (2000), Team Structure and Performance: Assessing the Mediating Role of Intrateam Process and the Moderating Role of Task Type, "Academy of Management Journal", 43: 135-148, http://dx.doi.org/10.2307/1556372.

Webber S. S., Donahue L. M. (2001), Impact of Highly and Less Job-related Diversity on Work Group Cohesion and Performance: A Meta-analysis, "Journal of Management", 27: 141-162, http://dx.doi.org/10.1177/014920630102700202.

Williams R. S. (2006), Managing Employee Performance: Design and Implementation in Organizations, "Psychology@Work".

\section{Ograniczenia i problemy w zarządzaniu efektywnością zespołów}

Wiele czynników może wpływać na efektywność zespołów: określenie jasnych i możliwych do osiągnięcia celów, indywidualny przydział obowiązków, wykorzystanie umiejętności danej osoby, monitorowanie wydajności, zachowanie spójności i tożsamości zespołu, umiejętność zarządzania wewnętrznymi konfliktami, relacje z innymi zespołami, a także systemy i źródła dostępne zespołom oraz jakość przywództwa. Wskazane problemy i ograniczenia wpływają na zarządzanie zespołową efektywnością i są znane powszechnie bez względu na indywidualną kulturę pracy danego kraju.

W niniejszej pracy przedstawiono naturę zarządzania efektywnością pracowników w celu wskazania powszechnych problemów i ograniczeń w zarządzaniu zespołową efektywnością w kontekście światowych wyników badań. Warto zaznaczyć, że czynniki środowiskowe i dynamika zespołu wpływają na zespołową efektywność. We wnioskach wskazuje się, że istnieje potrzeba dalszych badań w zakresie uchwycenia złożoności dynamiki zespołu wraz z upływem czasu.

Słowa kluczowe: zespół, zarządzanie efektywnością, model IMO, ograniczenia, problemy. 